\title{
A COMPARATIST PERSPECTIVE IN INTERCULTURAL RESEARCH AND IMAGOLOGY
}

\author{
MiLoš ZeLENKA ${ }^{1}$ \\ (Univerzita Konštantína Filozofa v Nitre)
}

\begin{abstract}
Słowa kluczowe: komparatystyka, imagologia, studia międzykulturowe, Dionýz Ďurišin, literatrura światowa, historia literatury

Key words: Comparative Studies, imagology, intercultural research, D. Ďurišin, World Literature, Literary History
\end{abstract}

\begin{abstract}
Abstrakt: Miloš Zelenka, PORÓWNAWCZA PERSPEKTYWA W BADANIACH MIĘDZYKULTUROWYCH I IMAGOLOGII. „PORÓWNANIA” 19, 2016. T. XIX. S. 21-31. ISSN 1733-165X. Współczesna komparatystyka oddala się od swojej ścisłej, przedmiotowej i metodologicznej definicji, stając się bardziej intelektualną refleksją, która jest interdyscyplinarnie powiązana poprzez aspekt porównawczy. Do najbardziej znaczących współcześnie inicjatyw w tym względzie należą badania międzykulturowe oraz tzw. imagologia. Podczas gdy komparatystyka studiuje dialog pomiędzy kulturami za pośrednictwem badania „inności”, imagologia poprzez obraz „swojego” i "cudzego" zajmuje się tematami i motywami „innych” w tekstach literackich, wykorzystując do tego obrazy ludzi bliskich i obcych. Te obrazy w większości powstają w fomie stereotypu lub mitu, za którymi stoją konkretne grupy społeczne i etniczne. Obie metody, które wykorzystują emocjonalne doświadczenia w literackiej komunikacji, mogą przyczynić się do dialogu między narodami (np. stosunki czesko-niemieckie albo słowacko-węgierskie).
\end{abstract}

\begin{abstract}
Miloš Zelenka, A COMPARATIST PERSPECTIVE IN INTERCULTURAL RESEARCH AND IMAGOLOGY. „PORÓWNANIA” 19, 2016. T. XIX. S. 21-31. ISSN 1733-165X. Abandoning its exact subject and methodological delimitation, contemporary comparative literature rather takes the form of intellectual reflection whose interdisciplinary linkage lies in the aspect of comparison. Among major contemporary initiatives, the most prominent are two, known as intercultural research and imagology. Whereas intercultural comparative studies explore interlocution between cultures through understanding "otherness", imagology deals with the themes and motifs of "other landscapes" in literary texts, using its own and other people's images. Such images mostly originate in the form of stereotypes and myths representing concrete social and ethnic communities. Thus both methods which exploit emotional experience in literary communication can advance dialogue between nations (e.g. Czech-German or Slovak-Hungarian relations).
\end{abstract}

1 E-mail Adress: zelenka.milos@centrum.cz 
Present-day comparative study abandons its traditional boundaries and, ceasing to be an institutionalised university discipline, it becomes a new mode of reading and interpretation, a specific type of intellectual reflection which communicates different spheres of knowledge. The Italian theorist Vittorio Strada assumes that comparative study implies an individually moulded view of the world which moves "on the point of intersection of several polymorphous and mutually unrelated loci in culture and literature" (Strada 513). Comparative literature thus cannot be considered a strictly defined, canonised science requiring a particular method (Guillén 413-415), but more emphasis is to be put on the protection of its boundaries against abstracted philosophical speculations moving away from the material. Peter V. Zima points out that comparative literary study must pursue continual theoretical substantiation of its foundations (Zima 2005: 47-62). Hence comparative study can hardly be replaced by literary sociology, cultural semiotics or media science, or dissolved in culturology or translatology; of all things, it should remain literary scholarship which does not shrink from entering the dialogue with other humanities. This concept regards comparative study as a form of dialogue leading to understanding one's own cultural identity, and difference as well, and so with respect to the varying subject and diverse methods of research, it does not represent an independent, special field of science. Rather it implies free delimitation of the values inherent in critical reflections where the comparative principle follows the horizon of wide-ranging cultural lines and paradigms and, terminologically, does not leave the area of regulative ideas. Comparative study should be developed deliberately as a metatheory (Kasperski 331-356) which gives up the partiality of empire and moves on the edge of terminality, interdisciplinarity and contacts of specific discourses; at the same time, comparative study must respect the integrity of the fields of science from which it draws its inspiration. It is its metatheoretical status that enables comparative study to reinterpret the contemporary labyrinth of literary scholarship as it communicates relations between its detailed segments, which often function independently. The Polish Slavonic scholar Bogusław Bakuła postulates an interesting thesis that comparative study comes out as an independent discipline at the level of metatheory and methodological presentation, and loses this status on approaching empire, i.e. textological researches or concrete analyses of an artefact (Bakuła 21-27).

One of the methodological initiatives of present-day comparative thought is represented by intercultural comparative study, which combines textual reality with researches into intercultural dialogue, multiculturalism and the philosophy of culture, mostly through hermeneutical impulses (Zelenka 2002: 34-58). Cultural comparative study then becomes the teaching of mutuality (reciprocity) whose interpretion of literary interaction or contact with "another" is grounded in comprehension; it investigates the processes and mechanisms of trading literary texts between cultures, explaining their differences in the area of mutuality and "creolisation" (Kučera 15-27). The roots of this process can be found in the stimuli for- 
mulated by Mikhail Bakhtin, a literary comparatist who pioneered the principles of dialogism, co-existence and encounter as a common denominator of phenomena characteristic of human existence. The Italian comparatist Armando Gnisci provocatively labelled comparative study as "practical didactics" expressing the very nature of literary study (Gnisci IX-XXI). His notion of comparative study, in contrast to the structural-morphological concept embraced by Central European scholarship, represents a certain ideological construct which emphasises reciprocity and complementarity of literary phenomena, namely by accentuating their differences and unsystematic dissimilarities. The comparative scholar is placed "amidst" affairs and events as a herald of hermeneutic peace, that is to say of mutual listening, which materialises through reading, learning and translating, and at the end of which is the noetic charge of new knowledge, or a pure pleasure from communication. Gnisci characterises this process as "hospitality culture" which emerges when the interpreting subject willingly accepts "the participation of the strange" in himself, when "the strangeness" becomes our spiritual foundation. In principle, mutual communication, transfer, exchange and translation of differences materialise in the course of mingling, touching or mixing (whereas Tzvetan Todorov metaphorically likens comparative scholars to homeless people and nomads, Gnisci views them as mestizoes, transsexuals and androids), which is a natural negation of the traditional Europocentric notion of the binary opposition between the centre and the periphery.

Intercultural comparative study not only explores the dialogue between cultures, but it also attempts to draw their boundaries. As intercultural are deemed mostly those literatures that thematise or cross the borders between cultures and subcultures, such as postcolonial literatures, literatures of ethnic minorities (microliteratures), migrant literatures, exile literature, etc. Correspondingly, it is necessary to examine how these "microliteratures" have developed their intercultural potential aesthetically, what intercultural effect their regional impulse exerts, for example, as regards poetology. Zima, the Austrian comparatist of Czech descent, finds the deficiency of present-day comparative study in slackening interdisciplinary dialogue, namely in losing contact with the humanities developing the method of comparison, such as comparative sociology, semiotics, contrastive linguistics, comparative pedagogy, and others. He conceives the discourse of literary history as a semiotic-narrative structure related within a specific sociolect and in accordance with particular group or individual interests. In this concept, comparative study represents a comparative, cultural and critical metatheory whose subject would be cultural and linguistic interferences in literature and theory.

The intercultural concept of comparative literary study highlights the aspect of receptive openness and communicative permeability of circulating texts and ideas. World literature thus changes not into a closed complex of forms and structures, but rather into an interliterary network of equal values which is instrumental in the nonviolent dialogue of worlds and cultures. Dionýz Ďurišin, the Slovak theoretician 
of interliterariness, points out that the "interliterary network" is conditioned by the complementarity of both purely intraliterary contactual-developmental agents and extraliterary contacting elements (Durišin 2000: 29-39). Whereas the former prevail in ethnic-linguistic communities, geographic-societal determinants come to the fore predominantly in centrisms. These, as natural forms of existence and functioning of world literature are rooted in Jauss' receptive aesthetics, based on the accommodating strategy of the recipient, on the horizons of his expectations (Koprda 153-168). Whereas in centrisms individual literatures are "neighbours", touching one another geographically and communicatively and getting to know one another metonymically in their own interest, which can even be discontinuous, the interliterary communication in communities is motivated metaphorically, because reception is based on the influence of transformational automatism. Ďurišin's division of great interliterary processes into interliterary communities and interliterary centrisms is, at the same time, discrimination between metaphorical intraculturality and metonymical interculturality. Basically, this discrimination results in two contradictory, mutually complementary, models of world literature: one, based on interliterary communities, reduces world literature to monocultural unity; the other, grounded in the theory of centrisms, postulates world literature, owing to the receptive aspect, as imaginary polycentric set preserving the individuality of single parts. In the comparatist systematics, the "world quality" refers to an open form of receptiveness, diffusing namely external contact agents, which, according to the American comparatist scholar Earle Miner, determine the intercultural nature of "interliterary network". The "world quality" may arise from subjective interpretational activity, but also from the ability of a literary phenomenon to simply accept a receptive stimulus positively.

Intercultural comparative study thus overcomes limitations that are typical of national philologies, e.g. the attempt to establish 'European' literature as a separate subject of study shows preference to literary creations of geographical regions, which are deemed literary areas and whose analysis within the context the study of national literatures is very difficult. It can be objected that European literature supresses the specific character of its national segments. In the intercultural concept, however, national literatures are not the only guiding points, rather, these are cultural regions, which are not limited by political frontiers or ethnic-linguistic barriers. As a classical example can serve Central Europe, a heterogeneous, Slavonic/ non-Slavonic area encompassing in its small space a great variety of ethnics, creeds and poetics whose literary and intercultural communication is analogical. Gayatri Ch. Spivak, the American comparative scholar of Bengali origin, in her book Death of a Discipline says that, overseen by powerful American elites, intercultural research in the past was focused on the "grey zones" of mixed cultures with undemocratic political and economic systems known as areas of international tensions. On that account, the reformed cultural studies should avoid bringing individual national liter- 
atures or literatures in particular countries or patriotic literatures into confrontation; rather, they should proceed to exploring all of these segments as multicultural entities, instead of subordinating cultural researches to the interests of the researcher and the culture that backs such study.

Similarly, Susan Bassnett in his Comparative Literature. A Critical Introduction warns that traditional comparative literature declines because of its inability to adapt to cultural changes. Cultural studies must give precedence to the classical canon over the canon of national literature and redefine the method which would involve a critique of various fields. Since the literary and sociological study of culture goes its own way, without any theoretical anchor, cultural processes do not meet the demands presented on them by 'academic scholarship'. Miner mentions three types of intercultural comparison (Miner 1999: 161-179): the first is based on proving the "otherness" through partial similarity. A familiar aspect of one culture is used to explain things that are less known in a different culture. The second method is grounded in exploring analogical functions in different contexts. The third method analyses a literary phenomenon whose morphology is identical in many cultures. It does not mean disclosing identity but cognition of commensurability or comparability based on diversity. And it is this - probably the most progressive mode of intercultural examination that justifies the premise that comparative literary research into the influence and "literary contact" does not need any metonymic "neighbourhood", i.e. geographical vicinity. Through creating a theoretical framework, intercultural researches then do not depend on genetic touch or empirical reception and are free to postulate universal propositions.

By the same token, Claudio Guillén, who refuses to comprehend literary history as bringing back an exhausted structure, discriminates three types of comparative study based on different models (resources) of supranationality. The first supranationality results from a genetic contact of diverse national cultures. The second is produced by typological links and explores literary phenomena from different cultural spheres which, although genetically independent, are determined by common social and historical conditions. The third supranationality materialises in a theoretical model, conceived by Guillén as an open conflict of history and criticism with theory. The comparatist verifies theoretical propositions not with the aim to confirm or negate them, but rather to develop and modify them. In this respect, Guillén often quotes Durišin, referring to his typological researches, which do not involve direct contact. The scholar's assertion that supranational textual collections can be produced with the help of extracontactual theoretical criteria (theory of culture; mythology; religion; linguistic, sociological and anthropological models, etc.) is valid only on condition that each phenomenon, element or work in such a collection is in empirically conclusive contact with the other works. Guillén's methodological position is unambiguously anti-Derridian and defensive against some present-day poststructuralist concepts. Literary history is not a history of restoring an 
exhausted structure, rather it is a dialectical search (Guillén refers here to the ability to perceive the complexity and mutability of the world), which permanently locates literary and cultural reality beween unity and diversity. The polarity between them is distinguishable, according to Guillén, particularly in one of the most productive types of modern comparative research, namely in East-West Studies, which integrate for example East European (Slavonic) literatures or Chinese and Japanese literatures into the world literary circulation while not imposing any universal order or norm derived from western Europocentrism. This violates the principle of paralellism between expression and content, which was anticipated by Jacobson and deemed as the ontological basis of a sign; e.g. Chinese poetry - positively older than European poetry - is based on formal virtuosity, namely variance in expression, which in principle ceases to be parallelistic.

Intercultural studies are interconnected with ,imagology', a discipline of literary scholarship which through the image (les images) of another (heteroimages) and of itself (autoimages) explores the topos of "another" in literary texts. These images mostly assume the character of stereotypes, myths, prejudices and clichés, and instead of offering a direct and mimetic reflection of reality, they rather express power interests and intellectual discourse of diverse ethnical and social groupings. Authors like to depict foreigners and foreign countries in order to emphasise not only closeness and understanding, but mainly the "otherness" of values and aesthetic tastes, or even superiority. Thus both individuals and social groups in the cognitive process do not objectively portray the substance or segments of extratextual reality, but through metaposition, i.e. linguistic and syntactic periphrases, create an ideological construction of the world. Obviously, imagological analyses can become a corrective to common sphere of research, which Paul van Tieghem labelled "littérature comparée" (compared literature). The stimulating nature of research on "national" myths or illusions through artistic (fictional) texts and the confrontation of "images", for example between neighbouring countries, points, as mentioned above, to certain independence of the outer (real) world, giving evidence of the aesthetics of identity and alterity in the interliterary space of a particular area.

The historical roots of imagology as a specific method lie at the beginning of the 1960s, when Konrad Adenauer and Charles de Gaulle laid the symbolic foundations of European integration which was unworkable without facing the traditional French-German reality, or rather without "transferring" it from the politically ideological level to the sphere of intellectual discourse. There is no need to emphasise what effect this approach to interliterary study has upon the compelling extension of national literature within the area of Central Europe (e.g. Czech-German or Slovak-Hungarian relations). The very term imagology modified by the adjective "comparatist" was first used in 1966 by Hugo Dyserinck, one of the originators of this method, in his study Zum Problem der "images" und "mirages" und ihrer Untersuchung im Rahmen der vergleichenden Literaturwissenschaft (Dyserinck 1996: 107-120). He bor- 
rowed it from a text authored by the French ethnologist Olivier Brachveld, who claimed that social groups get hold of the world around through cultural means, i.e. through subjective and permanent introducing into historical and cognitive processes the subjectivity of their thought constructs, of their ideologemes, which consequently seek political objectivisation. Hugo Dyserinck's programme of imagology was based on opposition to René Wellek, the American scholar of Czech origin, who consistently disclaimed this field of research as influential (Wellek 323-331), as the latest fad of the sociological history of artistic taste or 'national psychology'. Dyserinck was confronted in particular with the assertion that imagology by its very nature does not belong to literary scholarship since it pursues political aims. In fact, images, despite being seemingly neutral, have their "denotative" and "noetic" functions: as stereotypes, they occur not only in artistic texts but also in literary criticism, historiography and literary scholarship. Even the most general metapropositions about, e.g. specific features of a national character or idiosyncracy, convey biased and loose clichés and stereotypes which impede understanding among nations. According to Dyserinck, imagology is to contribute to deidiolisation of literary research, for the literary historian does not explore in his comparative study the qualities of one or another national literature in their confrontation, but searches for the qualities ascribed to particular literatures and asks what interest groupings benefit from individual functions.

Dyserinck, who with the help of his disciples (M. Fischer, K.U. Syndram and others) initiated the Aachen Programme (the concept of "Laboratorium Europa") focused on intraliterary and extraliterary functions and the meaning of images in European regions, conceived imagology as a method for transmuting problems of national mentalities into deidealised vision of national characters. In the 1980s, Dyserinck's theory was substentially amended by the French comparatist Daniel-Henri Pageaux, who approached some Slavonic concepts, namely Ďurišin's theory of reception and Lotman's communicative model (Pageaux 1991: 125-133, 187-188). Emphasising the receptive side, Pageaux thus attempted to counterbalance the prevalence of ,influenceology' in literary scholarship. Lotman, incidentally, views communication as our ability to understand one another by using different codes, and Durišin refers to the necessity to observe contactually close literatures in their mutual relations as if they were unrelated, as though they were linked only typologically. According to Pageaux, comparative literature must proceed to cultural anthropology; culture as study of man becomes a "workshop" producing images which function in interliterary communication. Through rereading artistic texts, the comparatist can create a synchronic and diachronic portrayal of the period and society, grasping thus more sensitively than a strict historian the meaning of "strange" and perceiving the actual rhythm of the historical process. The imagological approach does not classify texts according to aesthetic criteria but with respect to their thematic significance, and particularly according to their percipients' reception range. The central issue of imagology is to specify how objective are researches 
into relations between cultural works and social structures in concrete space and time. The textual analysis of the image of a stranger proceeds methodically from determining great binary oppositional structures through identifying big thematic units up to the linguistic level, which, too, depicts "otherness" through words. What has not been tackled so far is the "insoluble" problem of the "truthfulness" of the stranger's image, because, always representing someone, it is a substitute for someone, while the main priority is assigned to ideas and ideological systems which control "the image of a stranger". Thus imagology serves as a methodological starting point for producing alternative history of literature, with respect to its imagery. Whereas previous researches were characterised by scholarly exclusivity, with only one approach to reading the text, imagology claims the right of creating "brickolage" and layering methodological procedures by following from purely aesthetic analyses to historical and culturological research. The literary historian then has to abandon the ideal of objectivity, which has often been sought only in the text (positivists, structuralists, phenomenologists, communicationists, etc.); the results of his "reading" must always be compared with the given cultural and social conditions and referred to the past as well as to the present-day needs.

In the last twenty years, imagology has evolved into two streams: towards literary research and towards anthropological analysis of the history of mentalities. In the former concept, imagology remains a specific method of literary analysis where, under the influence of the methods of new historism and intercultural communication, the work of literature is conceived as a form of social interaction. Literature as a historical and cultural construct is not shaped only by authors but also by the societal discourse which likewise produces literary stereotypes. Therefore imagology examines the origin of the function and structural mechanisms of theses stereotypes which manifest the qualities of nations and ethnical or other groupings. In the monumental publication Imagology. The Cultural Construction and Literary Representation of National Characters (2007), its editors Manfred Beller and Joep Leerssen define individual terms and categories of the imagological method from the point of view of their natural diversity, such as literary stereotype (autostereotype as a group's own established notion of itself; heterostereotype as notion related to the "others"); literary image; topos; cliché; national symbol etc.

In the latter concept imagology was inspired by the works of respected ethnologists and theorists of nation: Ernest Gellner; Anthony D. Smith; Benedict Anderson; and further, by the theory of ethnoimage of the Dutch scholar Joep Leersen, who conceives imagology as research into imagems, i.e. differentiated national images offering pluralist interpretational possibilities within one stereotype. A strong stimulus for the study of ethnoimages is also represented by the imagological concept of the Iranian semiotician Bahman Namvar Motlagh, who percieves stereotype as a form of canonised literary image prevailingly determined by sociological stand points and therefore, on the whole, she regards imagology as a partial component of ethnopsychology. 
As a result of new rapprochement between sciences and humanities, the subject of imagology is widened by the study of the images of animals and things in culture, irrespective of the streams and concrete application of contemorary imagology. That is why a new concept of imagology becomes consolidated as an interdisciplinary branch of cultural and literary comparative studies whose main focus remains enquiry into "otherness", not inly in the form of national and ethnic stereotypes but also literary images in biological, sexual or material heterogeneity. After 1989 the imagological reflections from the Anglo-Saxon world and Western Europe penetrate into Slavonic-nonSlavonic surroundings of Central and Eastern Europe, namely to regions featuring a specific, ethnic and national as well as religious situation. Apart from bringing about the danger of open politicisation of imagological method, the new perspective introduces other methodological problems, specifically the link between aesthetic value and the character of the national image viewed from its aesthetic delimitation. Another issue is related to the general validity and adequacy of transferring the terminology and semantics of imagological concepts, invented mainly in the French-German confrontation, to Central Eastern Europe where the image of "neighbour" was structurally shaped in different conditions.

The last AILC congresses view comparative studies as an attacking, "aggressive" discipline, or a thematic area which proclaims itself as an apparent and alternative theory of literature (Janaszek-Ivaničkova 333-341). The microscopic dismantling of the so far widespread themes is balanced by a call for new "universality", culminating the methodological movement through which comparative literary studies acquires the nature of "absolute literature", which, by means of its method and study field, geographically and nationally exceeds the set borders and widens its cognitive horizons. Current situation of "comparative studies under discussion", whose aim is to adequately come to terms with the consciousness of the world's multicultural nature, gives clear signals that under the surface of the idea of a prolonged progress of the developing literary critical methodologies there is a hidden, sometimes even chaotic movement spread out to sides, numerous semantic tensions, where nothing stays forgotten and mechanically surpassed, where individual pieces of knowledge get just eliminated, over-stratified and mutually crossed. By the way, "progress" or line of development in the field of comparative studies is not so much given by the generation of the so far unknown categories: what happens is rather a restructuralisation and a different functional loading of current terms which, through new naming and inclusion into non-traditional relations, acquire a new meaning. It is evident that modern comparative studies was, in this period, developing from investigation of interliterary correspondences and reception dependencies of individual national literatures through interdisciplinary study to the so-called transcultural investigations, i.e. to cultural anthropology and culturological criticism. In the era of poststructural performances it is possible to detect, in spite of common starting points, two developmental lines - mutually competing and 
complementarily interconnected: the intertextual and the cultural-analytical comparative studies (Šeleva 21-30). While the first of them applies the issue of dialogism and innovated reception aesthetics, giving preference to the act of interpretation of (inter)text, in which it studies transformation mechanisms and immanent structural rules, the second line connects textual reality with the investigation of intercultural dialogue, multiculturalism and the philosophy of culture, most often through hermeneutic impulses which, in various intensity, determine new theoretical acts (gender studies, cultural studies, imagology, emigrantology, postcolonial criticism, etc.).

It can be concluded that intercultural comparative study and imagology represent a functional link between traditional philology and area researches, which may contribute to more precise identification and understanding of the world at a watershed from the very cultural and aesthetic perspectives. At the same time, intercultural comparative study and imagology confirm a definite withdrawal from formalist-structuralist theories for the sake of anthropology and culturological study. It is a transition from ontological concept to epistemological delineation of comparative study which may become the last "chance" for literary scholarship as it aspires to be the imaginary "pangramatology" of humanities.

\section{BIBLIOGRAPHY}

Bakuła, Bogusław. Historia i komparatystyka. Poznań: Poznańskie Studia Polonistyczne, 2000.

Bassnett, Susan. Comparative Literature. A Critical Introduction. Blackwell: Oxford UK \& Cambridge, 1993.

Beller, Manfred, Leerssen, Joep, eds. Imagology. The cultural construction and literary representation of national characters. A critical survey. Amsterdam - New York: Rodopi, 2007.

Dolinar Darko, Juvan Marko, eds. Primerjalna književnostv 20. stoletju in Anton Ocvirk. Ljubljana: Založba ZRC SAZU, 2008.

Dolinar Darko, Juvan Marko, eds. Writing Literary History. Selected Perspectives from Central Europe. Frankfurt am Main: Peter Lang Verlag, 2006.

Dyserinck, Hugo. "Zum Problem der "images" und "mirages" und ihrer Untersuchung im Rahmen der Vergleichenden Literaturwissenschaft". Arcadia 1 (1996). P. 107-120.

Dyserinck, Hugo. Komparatistische Imagologie jenseits von "Werkimmanenz" und "Werktranszedenz". Synthesis 9 (1982). P. 27-39.

Dyserinck Hugo, Syndram Karl Ulrich, eds. Europa und das nationale Selbstverständnis. Imagologische Probleme in Literatur, Kunst und Kultur des 19. und 20. Jahrhunderts. Bonn: Bouvier, 1988.

Ďurišin Dionýz, Gnisci Armando, eds. Mediterraneo. Una rete interletteraria. La Méditerranée. Un réseau interlittéraire. Stredomorie. Medziliterárna siet'. Roma: Bulzoni, 2000.

Fischer, Manfred. Nationale Images als Gegenstand Vergleichender der Literaturgeschichte. Untersuchung zur Entstehung der komparatistischen Imagologie. Bonn: Bouvier, 1981.

Gellner, Ernest. Nacionalismus. Brno: Centrum pro studium demokracie a kultury, 2002.

Gnisci, Armando. Introduzione alla letteratura comparata. Milano: Bruno Mondadori, 1999. 
Guillén, Claudio. Mezi jednotou a růzností. Úvod do srovnávací literární vědy. Praha: Triada, 2008.

Janaszek-Ivaničkova, Halina. “O ambiwalencjach współczesnej komparatystyki literackiej”. Przegląd Humanistyczny, 41 (1997). P. 333-341.

Kasperski, Edward. “O teorii komparatystyki”. Literatura. Teoria. Metodologia. Ed. D. Ulicka. Warszawa: PIW, 1998. P. 331-356.

Koprda, Pavol. “Jaussova recepčná estetika a interkultúrne centrizmy (Medziliterárna komunikácia je otváranie sa prijímajúceho seba)". Slovak Review 8 (1999). P. 153-168.

Kučera, Petr. “K interkulturnímu směru v literární komparatistice”. Kultúra a súčasnost' 6 (2008). P. 15-27.

Miner, Earle. Comparative poetics. An intercultural Essays on Theories of Literature. New Jersey: Princeton, 1990.

Miner, Earle. "Études comparées interculterelles". Théorie littéraire. Problèmes et perspectives. Eds. T.M. Angenot, J. Bessière, D. Fokkema, E. Kushner. Paris: PUF, 1999.

Motlaghová, Bahman Namvar. “Les stéréotypes à travers le prisme de $\mathrm{l}^{\prime}$ imagologie". Recherches en Langue et Littérature Françaises Revue de la Faculté des Lettres 5, 7 (2011). P. 61-81.

Pageaux, Daniel Henri. Komparatistik. Eine Einführung. Bonn: Bouvier, 1991.

Pageaux, Daniel Henri. "L’imagerie culturelle: de la littérature comparée à l'anthropologie culturelle". Synthesis 10 (1983). P. 79-88.

Spivak, Gayatri Chakravorty. Death of Discipline. New York: Columbia University Press, 2003.

Strada, Vittorio. “Čitat' i sravnivat”". Sbornik statej k 70-letiju prof. Ju. M. Lotmana. Tartu: Tartu University Press, 1992.

Šeleva, Jelena. "Metod i prošetka (Komparativistika denes)". Kniževen kontekst. Sporedbeni kniževni istražuvanje. Skopje: Institut za makedonska literatura, 1999.

Tötösy de Zepetnek, Steven. Comparative Literature: Theory, Method, Application. Amsterdam-Atlanta: Rodopi, 1998.

Wellek, René. “Krize srovnávací literatury”. Západníliterární věda a estetika. Ed. J. Levý. Praha: Československý spisovatel, 1966.

Virk, Tomo. Primerjalna knjižeonost na prelomu tisočletja. Kritični pregled. Ljubljana: Založba ZRC SAZU, 2007.

Zelenka, Miloš. "Hranice a křižovatky současné komparatistiky. Stav a perspektivy." Slavia 67 (1998). P. 491-500.

Zelenka, Miloš. Literární věda a slavistika. Praha: Academia, 2002.

Zima, Peter. Komparatistik. Einführung in die Vergleichende Literaturwissenschaft. Tübingen: A. Francke,1992.

Zima, Peter. "Komparatistik und Sozialwissenschaften." Komparatistik. Jahrbuch der Deutschen Gesellschaft für Allgemeine und Vergleichende Literaturwissenschaft (2005). P. 47-62.

Zima, Peter. Moderne/Postmoderne. Gesellschaft, Philosophie, Literatur. Tübingen und Basel: A. Francke, 1997. 